\title{
The influence of physical exercise on the generation of TGF- $\beta 1$, PDGF-AA, and VEGF-A in adipose tissue
}

\author{
Bozena Czarkowska-Paczek • Malgorzata Zendzian-Piotrowska • \\ Irena Bartlomiejczyk · Jacek Przybylski · Jan Gorski
}

Accepted: 7 October 2010/Published online: 23 October 2010

(C) The Author(s) 2010. This article is published with open access at Springerlink.com

\begin{abstract}
Adipose tissue is an important organ that produces and secretes hormones and cytokines, including TGF- $\beta 1$, PDGF-AA, and VEGF-A. The goal of the present study was to investigate the influence of a single session of acute exercise, as well as the prolonged endurance training on the production of TGF- $\beta 1$, PDGF-AA, and VEGF-A in the subcutaneous white adipose tissue in rats. Rats were randomly divided into two groups: untrained (UT, $n=30$ ) and trained rats ( $\mathrm{T}$, subjected to 6-week endurance training with increasing load, $n=29$ ). Both groups were subjected to an acute exercise session with the same work load. The rats were killed before (UTpre, Tpre), immediately after (UT0h, T0h), or $3 \mathrm{~h}$ (UT3h, T3h) after exercise and adipose tissue samples collected. Growth factor mRNA was evaluated using RT-PCR; the protein levels were measured before and after training (UTpre and Tpre) using the immunoenzymatic method. TGF- $\beta 1$ and PDGF-AA mRNA levels were decreased in the UT3h rats compared to the UTpre rats $(P=0.0001$ and $P=0.03$, respectively), but the VEGF-A mRNA level remained unchanged in the
\end{abstract}

Communicated by Susan Ward.

B. Czarkowska-Paczek $(\bowtie) \cdot$ J. Przybylski

Department of Biophysics and Human Physiology,

Medical University of Warsaw, Chalubinskiego Str. 5,

02-004 Warsaw, Poland

e-mail: dom_paczek@o2.pl

M. Zendzian-Piotrowska · J. Gorski

Department of Physiology, Medical University of Bialystok,

Mickiewicza Str. 2C, 15-222 Bialystok, Poland

I. Bartlomiejczyk

Department of Immunology Transplantology, and Internal

Diseases, Medical University of Warsaw, Nowogrodzka Str. 59,

02-005 Warsaw, Poland
UT0h and UT3h rats compared to UTpre rats. TGF- $\beta 1$, PDGF-AA and VEGF-A mRNA levels were decreased in the T3h rats compared to Tpre $(P=0.0002, P=0.02$, and $P=0.03$, respectively). TGF- $\beta 1$, PDGF-AA and VEGF-A mRNA levels significantly increased in the Tpre rats compared to UTpre (all $P=0.0002$ ). However, the protein levels remained constant. In conclusion, prolonged physical exercise increases growth factor mRNA in adipose tissue but not protein levels.

Keywords TGF- $\beta$ - PDGF - VEGF - Physical exercise · Adipose tissue

\section{Introduction}

It is widely accepted that white adipose tissue (WAT), visceral and subcutaneous, is an important endocrine organ, producing and secreting several hormones and cytokines. These signalling proteins have been given the collective name "adipokines" and facilitate a number of metabolic actions, such as lipid metabolism, energy balance, insulin sensitivity, angiogenesis, and vascular homeostasis. Adipokines are also involved in inflammatory and immunologic responses (Trayhurn and Wood 2004). Adipokines production, including growth factors, is increased in obesity, making obesity comparable to a lowgrade inflammatory process, linking it with insulin resistance, metabolic syndrome, and, further, with the increased risk of cardiovascular disease (Antuna-Puente et al. 2008).

The protective and therapeutic influence of physical exercise in metabolic and cardiac diseases is well known; however, the detailed mechanism is not fully understood (Thompson et al. 2003; Warren et al. 2005). Physical exercise influences immunological and inflammatory 
reactions by changing the serum levels of particular cytokines and other mediators of these reactions, including growth factors (Czarkowska-Paczek et al. 2006; Banfi et al. 2008). Physical exercise could alter cytokine production and release from the adipose tissue.

There is very limited data on the influence of physical exercise on the activity of adipose tissue. However, it was shown that endurance training had greater influence on adipokines produced in subcutaneous WAT, than in visceral WAT. For instance, after endurance training performed by the rats during 4 weeks, the expression of mRNA for several cytokines (Il-6, TNF-alfa, Il-1Ra) did not change in visceral WAT, while it increased significantly in the subcutaneous WAT. This phenomenon indicates the possibility of the specific role of subcutaneous WAT in adaptive response to exercise training (Gollisch et al. 2009). It was confirmed by other studies in regard to other adipokines, Il-18 and visfatin (Leick et al. 2007; Frydelund-Larsen et al. 2007). On the other hand, 6 months of aerobic training of various intensity leading to a decrease in adipose tissue stores does not cause any changes in the serum levels of 27 investigated cytokines (Huffman et al. 2008). No relationship has been observed between changes in body composition and cytokine levels.

It is not yet known whether physical exercise alters growth factor production in subcutaneous WAT.

The goal of the present study was to investigate the influence of a single session of acute exercise in untrained and trained rats and the prolonged endurance training on TGF- $\beta 1$, PDGF-AA, and VEGF-A production in the subcutaneous WAT in rats.

\section{Methods and procedures}

Fifty-nine male Wistar rats were used in the study. Animals were provided water and food (Labofeed B) ad libitum throughout the study period, and a 12-h day/night (12/ $12 \mathrm{~h}$ ) rhythm was sustained.

At the beginning of the experiment, the rats were subjected to exercise adaptation consisting of $10 \mathrm{~min}$ of treadmill running at $15 \mathrm{~m} / \mathrm{min} /$ per day for five successive days. After adaptation, rats were randomly assigned to two groups: untrained (UT, $n=30$ ) and trained (T, $n=29$ ), which consisted of prolonged endurance training. The mean body mass of rats at the beginning of the experiment was $127 \pm 13.85$, and $379.75 \pm 51.63 \mathrm{~g}$ on the day of killing.

Prolonged training of the $\mathrm{T}$ group consisted of treadmill running 5 days a week for 6 weeks. During the first week, $1,200 \mathrm{~m} / \mathrm{h}$ was a constant speed and the exercise time increased $10 \mathrm{~min}$ each day, starting from $10 \mathrm{~min} /$ per day. During the second week, the workload was constant and consisted of $60 \mathrm{~min}$ of treadmill running at $1,500 \mathrm{~m} / \mathrm{h}$. Finally, during weeks $3-6$, the rats reached the daily exercise of $60 \mathrm{~min}$ of running at $1,700 \mathrm{~m} / \mathrm{h}$. The UT group remained at rest during the whole training period. Twentyfour hours after the last training session, each group was randomly divided into three subgroups. One subgroup was killed before the other rats were submitted to an acute exercise session (UTpre, $n=10$ and Tpre, $n=9$ ), and white subcutaneous adipose tissue samples from the lower part of abdomen were collected while under anaesthesia (intraperitoneal Chloral Hydrate, $1 \mathrm{ml} / 100 \mathrm{mg}$ body mass) and stored at $-80^{\circ} \mathrm{C}$ for subsequent analysis. Other samples (heart) were collected during the same experiment; removal of the heart caused the death of the rats. Another type of adipose tissue, brown adipose tissue, which is mainly connected with heat generation and maintaining of body temperature in cold environments, is also present in rats. It is located in identifiable clusters: interscapular, surrounding the kidney and aorta, and intercostal, so it is impossible that this type of adipose tissue is included in the analyzed samples (Mattson 2010).

The rest of the rats were then subjected to an acute exercise session consisting of $60 \mathrm{~min}$ of treadmill running at $1,700 \mathrm{~m} / \mathrm{h}$. Subcutaneous adipose tissue samples from the same localization were collected from the other subgroups immediately after the cessation of acute exercise (UT0h, $n=10$ and T0h, $n=10$ ) or $3 \mathrm{~h}$ after exercise (UT3h, $n=10$ and T3h, $n=10$ ) as described above.

The TGF- $\beta 1$, PDGF-AA, and VEGF-A mRNA expression was determined in all collected samples. TGF- $\beta 1$, PDGF-AA, and VEGF-A protein levels were measured before and after training (UTpre and Tpre).

Analytical methods

Approximately $50 \mathrm{mg}$ of tissue was homogenized in a bead-mixer TissueLyser (Qiagen, Germany). Total mRNA isolation was performed using the EZ1 RNA Universal Tissue Kit and Biorobot EZ1 (Qiagen, Germany) according to the manufacturer's protocol. Total mRNA concentrations were measured at $260 \mathrm{~nm}$ using a NanoDrop ND1000 (NanoDrop Technologies, USA) spectrophotometer. Samples were stored at $-80^{\circ} \mathrm{C}$ until further analysis.

Reverse transcription (RT) of total mRNA was performed using Thermomixer Comfort (Eppendorf, Germany) with the SuperScript III First-Strand Synthesis System for RT-PCR (Invitrogen, USA) according to the manufacturer's recommended method. mRNA detection was performed on an ABI-Prism 7700 Sequence Detection System (Applied Biosystems, Foster City, CA, USA). PCR was performed using the RT product and reaction mixture containing TaqMan Universal PCR Master Mix (polymerase and dNTPs), gene-specific primers, and nuclease- 
free water (Applied Biosystems, Foster City, USA) in a total volume of $20 \mu \mathrm{l}$. PCR amplification consisted of an initial step of $50^{\circ} \mathrm{C}$ for $2 \mathrm{~min}$ and $20 \mathrm{~min}$ at $95^{\circ} \mathrm{C}$, followed by 40 cycles of $95^{\circ} \mathrm{C}$ for $15 \mathrm{~s}$ and $60^{\circ} \mathrm{C}$ for $1 \mathrm{~min}$. PCR for a reference gene, GAPDH (glyceraldehyde-3-phosphate dehydrogenase), was performed for each sample, and a no template control (NTC) was performed for each reaction.

Adipose tissue samples were homogenized in a beadmixer TissueLyser (Qiagen, USA). Following $10 \mathrm{~min}$ of centrifugation at 3,000 rpm, the supernatant was separated and stored at $-80^{\circ} \mathrm{C}$ until further analysis. The total protein concentration in an adipose tissue sample was measured at $562 \mathrm{~nm}$ using a Bio-Tek Power Wave XS (Bio-Tek Instruments, USA) spectrophotometer and bicinchoninic acid (BCA) test Protein Assay Reagent (Pierce, Beijerland, Holland) according to the manufacturer's instructions.

Latent TGF- $\beta$ was activated by incubating the protein with $1 \mathrm{~N} \mathrm{HCl}$ at room temperature for $10 \mathrm{~min}$, followed by neutralization with $1.2 \mathrm{~N} \mathrm{NaOH/0.5} \mathrm{M} \mathrm{HEPES.} \mathrm{The} \mathrm{tissue}$ concentration of TGF- $\beta 1$ protein was measured immediately after activation and neutralization using the Quantikine Human TGF- $\beta 1$ Immunoassay (R\&D Systems, Minneapolis, MN, USA). This assay recognizes both human and rat TGF- $\beta 1$.

The tissue concentration of PDGF-AA protein was measured using the Quantikine Human/Mouse PDGF-AA Immunoassay kit (R\&D Systems, Minneapolis, MN, USA). The tissue concentration of VEGF protein was measured using the Quantikine Rat VEGF Immunoassay (R\&D Systems, Minneapolis, MN, USA).

\section{Statistical analysis}

The data were analysed using the comparative cycle threshold $\left(C_{\mathrm{T}}\right)$ method. The $C_{\mathrm{T}}$ of each sample was normalized to the expression of GAPDH, so the results are shown as $\Delta C_{\mathrm{T}}$. The relative mRNA for the investigated growth factors was calculated by subtracting the normalized $C_{\mathrm{T}}$ values for the investigated groups (exp) relative to the medium control (ctr) $\left(\Delta \Delta C_{\mathrm{T}}=\Delta C_{\mathrm{T}} \exp -\Delta C_{\mathrm{T}} \mathrm{ctr}\right)$, and the relative fold change of the growth factor mRNA was calculated according to the formula $2^{-\Delta \Delta C T}$ (Livak and Schmittgen 2001).

Results are provided as mean values \pm SD (tables) and relative fold changes (figures).

The difference in mRNA between investigated groups was analysed with the Kruskal-Wallis non-parametric ANOVA followed by a post hoc Duncan test. Pre- and post-training protein values were compared using the Student's $t$ test for independent samples. A $P$ value of $<0.05$ was considered significant.

\section{Results}

The mRNA and protein levels and standard deviations are shown in Table 1. The relative change in mRNA after an acute exercise session is shown in Fig. 1. There was a significant decrease in TGF- $\beta 1$ and PDGF-AA mRNA expression $3 \mathrm{~h}$ after the exercise in untrained rats ( $P=0.0001$ and $P=0.03$, respectively), but there was no change in VEGF-A mRNA expression in untrained rats immediately or $3 \mathrm{~h}$ after exercise. In trained rats, a significant decrease in TGF- $\beta 1$, PDGF-AA, and VEGF-A mRNA expression was observed $3 \mathrm{~h}$ after exercise ( $P=0.0002, P=0.02$, and $P=0.03$, respectively).

The relative TGF- $\beta 1$, PDGF-AA, and VEGF-A mRNA and protein levels in adipose tissue after prolonged endurance training are shown in Fig. 2. There was a significant increase in TGF- $\beta 1$, PDGF-AA, and VEGF-A mRNA (all $P=0.0002$ ) after training compared to untrained rats, but the protein levels of the investigated growth factors remained constant.

Table 1 TGF- $\beta 1$, PDGF-AA, and VEGF-A mRNA and protein expression in the adipose tissue of trained and untrained rats after acute bout of exercise

\begin{tabular}{|c|c|c|c|c|c|c|}
\hline & \multicolumn{3}{|c|}{ Untrained (UT) } & \multicolumn{3}{|c|}{ Subjected to training $(\mathrm{T})$} \\
\hline & UTpre & UTOh & UT3h & Tpre & $\mathrm{T} 0 \mathrm{~h}$ & $\mathrm{~T} 3 \mathrm{~h}$ \\
\hline TGF- $\beta 1 \Delta C_{\mathrm{T}} \pm \mathrm{SD}$ & $3.04 \pm 1.33$ & $4.23 \pm 1.62$ & $5.72 \pm 0.94$ & $-1.18 \pm 1.64$ & $0.89 \pm 3.50$ & $2.14 \pm 2.66$ \\
\hline TGF- $\beta 1$ protein $(\mathrm{pg} / \mu \mathrm{g}) \pm \mathrm{SD}$ & $0.20 \pm 0.05$ & & & $0.18 \pm 0.03$ & & \\
\hline PDGF-AA $\Delta C_{\mathrm{T}} \pm \mathrm{SD}$ & $4.67 \pm 1.50$ & $5.63 \pm 1.64$ & $6.03 \pm 1.12$ & $0.24 \pm 1.92$ & $2.06 \pm 3.21$ & $3.27 \pm 2.61$ \\
\hline PDGF-AA protein $(\mathrm{pg} / \mathrm{mg}) \pm \mathrm{SD}$ & $9.12 \pm 1.60$ & & & $9.05 \pm 2.65$ & & \\
\hline VEGF-A $\Delta C_{\mathrm{T}} \pm \mathrm{SD}$ & $1.82 \pm 1.02$ & $2.04 \pm 1.23$ & $1.79 \pm 0.51$ & $-2.05 \pm 1.70$ & $-1.09 \pm 2.71$ & $0.23 \pm 2.00$ \\
\hline VEGF-A protein $(\mathrm{pg} / \mathrm{mg}) \pm \mathrm{SD}$ & $7.66 \pm 10.42$ & & & $5.94 \pm 4.71$ & & \\
\hline
\end{tabular}

mRNA is expressed as $\Delta C_{\mathrm{T}} \pm \mathrm{SD}$, after the normalization of $C_{\mathrm{T}}$ to the expression of GAPDH. Protein level is expressed in pg/mg or pg/ $\mu \mathrm{g}$ of total protein $\pm \mathrm{SD}$ 
Fig. 1 The relative TGF- $\beta 1$, PDGF-AA, and VEGF-A mRNA changes in the adipose tissue of untrained (UT, a) and trained $(\mathrm{T}, \mathbf{b})$ rats after a session of acute exercise. Samples were collected for before the exercise (UTpre, Tpre), just after the cessation of exercise (UTOh, $\mathrm{T} 0 \mathrm{~h})$, and $3 \mathrm{~h}$ after exercise (UT3h, T3h). There was significant decrease in TGF- $\beta 1$ and PDGF-AA mRNA

expression $3 \mathrm{~h}$ after exercise in untrained rats. In trained rats, a significant decrease in TGF- $\beta 1$, PDGF-AA, and VEGF-A mRNA expression was observed $3 \mathrm{~h}$ after exercise $(* P=0.01$, $* * P=0.02, * * * P=0.003$, $* * * * P=0.0001)$
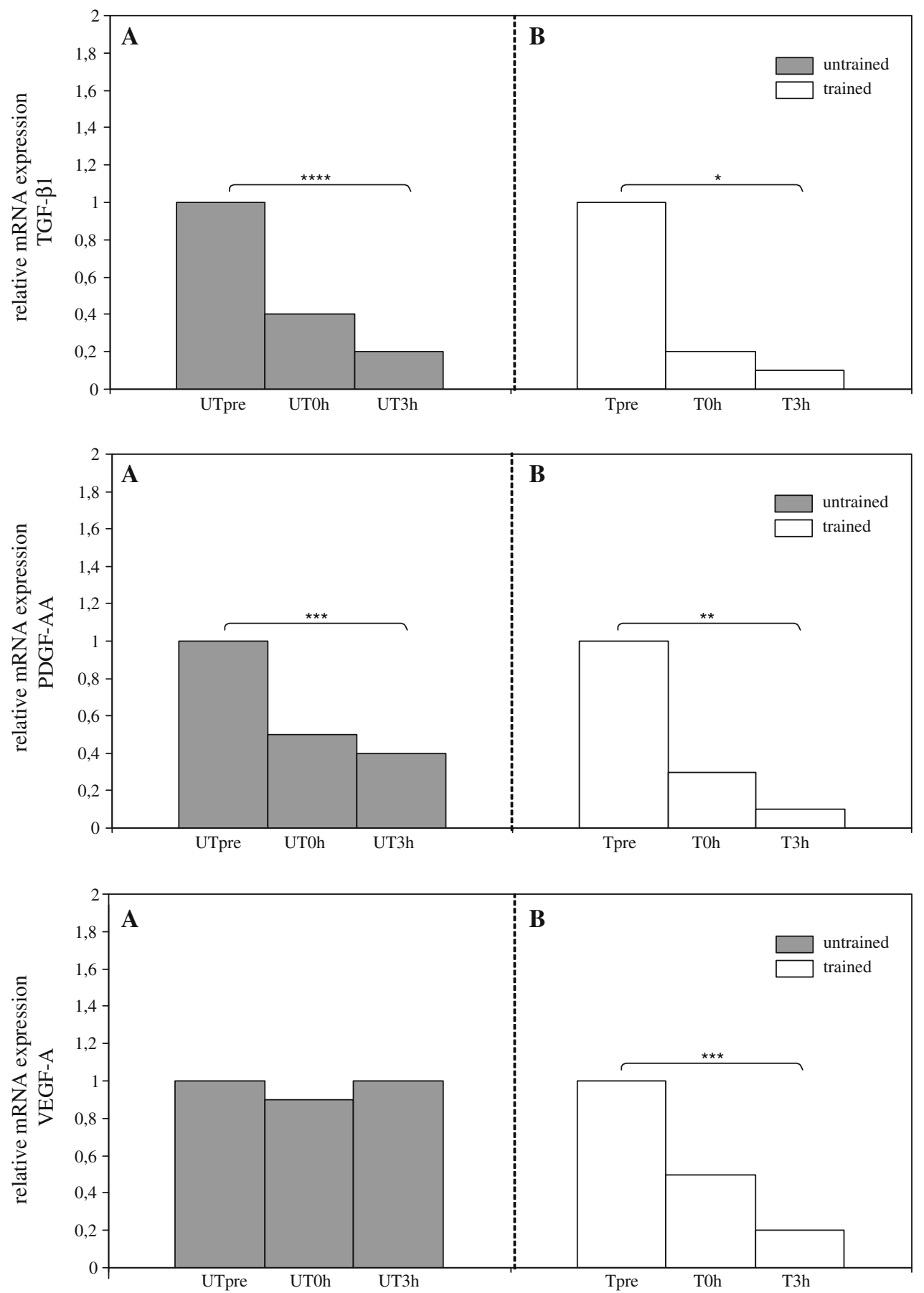

\section{Discussion}

To our knowledge, this is the first study assessing the influence of physical exercise on growth factor generation in subcutaneous WAT.

Pallua et al. (2009) showed that adipose tissue contains significant quantities of growth factors, including VEGF and PDGF-BB. Adipokines are assumed to contribute to metabolic syndrome genesis, insulin resistance, and increased cardiovascular risk (Trayhurn and Wood 2004).
There is a significant correlation between body mass index (BMI) and the presence and release of TGF- $\beta 1$ in subcutaneous adipose tissue, (Fain et al. 2005; Alessi et al. 2000) and TGF- $\beta 1$ influences adipocyte metabolism and potentialy inhibits the differentiation of preadipocytes into adipocytes, inhibiting adipogenesis (Richardson et al. 1998; Tan et al. 2008). On the other hand, TGF- $\beta 1$ promotes the production of plasminogen activator-1 (PAI-1) in adipose tissue, which is associated with insulin resistance in humans (Alessi et al. 2000). Very little is known about the 
Fig. 2 The relative TGF- $\beta 1$, PDGF-AA, and VEGF-A mRNA changes (a) and protein levels (b) in adipose tissue after prolonged endurance training (T) compared to untrained rats (UT). There was a significant increase in TGF- $\beta 1$, PDGF-AA, and VEGF-A mRNA after training $(* P=0.0002)$, but the protein level remained constant
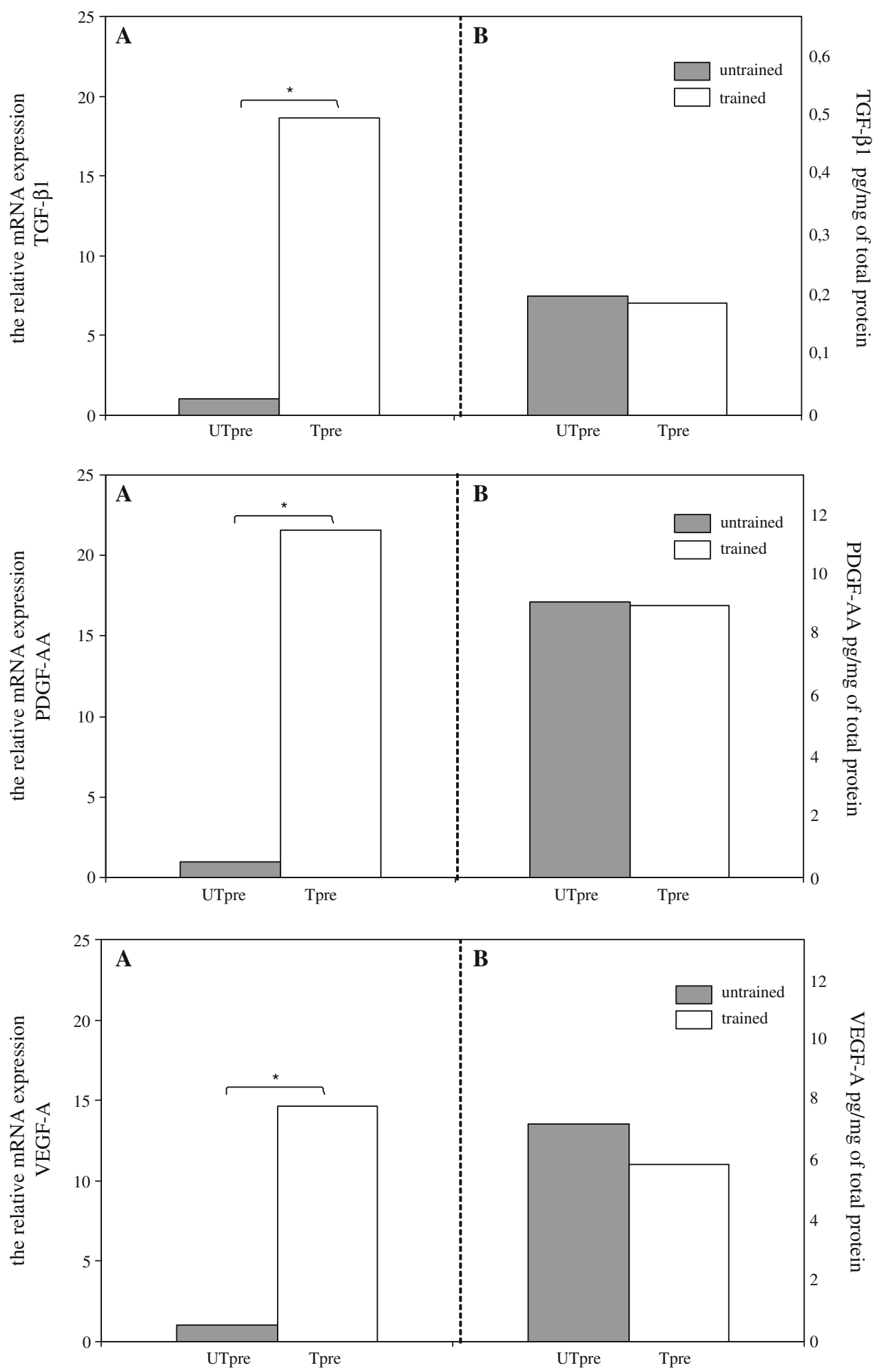

PDGF in adipose tissue. The exposure of preadipocytes to macrophage-conditioned medium promotes preadipocyte survival in a PDGF-dependent manner (Molgat et al. 2009). VEGF promotes angiogenesis in newly formed adipose tissue, contributing to adipogenesis. The blockade of
VEGF receptor-2 (VEGFR2) limits adipose tissue formation in diet-induced obesity (Iam et al. 2009).

The results of the present study indicate that prolonged physical exercise is a strong stimulus for the expression of TGF- $\beta 1$, PDGF-AA, and VEGF-A mRNA in adipose 
tissue, but it is not followed by a proportional increase in protein levels.

The mechanism underlying the increased mRNA expression remains unclear. The expression of these genes, as well as many others, is augmented by hypoxia inducible factor-1 (HIF-1). The main trigger for increased HIF-1 is tissue hypoxia. The results of the present study indicate that the increase in mRNAs for growth factors after acute exercise could occur later than $3 \mathrm{~h}$ into recovery from acute exercise and accumulates after the whole training period. During that time, hypoxia in the adipose tissue must be assumed to be non-existent. But it is also known that other factors than hypoxia could be responsible for augmentation of HIF-1 in tissues (Lundby et al. 2006; Trayhurn et al. 2008a, b). Factors responsible for growth factors mRNA increase could also origin in tissues other than adipose, and reach the target tissue via an endocrine manner. VEGF mRNA expression is induced in adipose tissue by free fatty acids (FFA) and interleukin-6 (Il-6) (Kawamura et al. 2008; Rega et al. 2007). Il-6 is produced in contracting muscle, and its serum level increases immediately after ceasing acute exercise (Czarkowska-Paczek et al. 2005, Pedersen and Febbraio 2008).

The discrepancy between mRNA and protein expression in the adipose tissue is of great interest. The level of signalling protein determines the cellular phenotype and its plasticity in response to external signals. In mammalian cells, the correlation coefficient between the mRNA and protein level is less than 0.5 (Pradet-Balade et al. 2001). The discrepancy argues for an additional control mechanism, such as mRNA localization, transcript stability, post-translational regulation, and protein degradation. Stress conditions influence post-transcriptional regulation; for instance, glucose and amino acid starvation and oxidative burst, all accompanying physical exercise, trigger such regulation, especially in the initiation phase of translation (Halbeisen et al. 2008; Sonenberg and Hinnebusch 2009). We cannot indicate the particular mechanism responsible for the observed discrepancy between mRNA and protein expression based on our results.

We can speculate as follows: physical exercise induces signals that increase the expression of TGF- $\beta 1$, PDGF-AA, and VEGF-A mRNA in adipose tissue. Physical exercise simultaneously induces complex post-transcriptional regulation, resulting in constant levels of growth factor protein despite increased mRNAs levels. We hypothesize that physical exercise exerts its beneficial role against metabolic and cardiovascular diseases not only by decreasing the amount of adipose tissue, but also by regulating transcription and, consequently, the level of potentially harmful or beneficial factors in adipose tissue.
Acknowledgments These studies were funded by the Warsaw Medical University (Grant no. NZME/W1). The study was approved by the Local Ethical Committee no II of the Medical University of Warsaw, Poland and was performed according to UE regulations.

Conflict of interest The authors declare that they have no conflict of interest.

Open Access This article is distributed under the terms of the Creative Commons Attribution Noncommercial License which permits any noncommercial use, distribution, and reproduction in any medium, provided the original author(s) and source are credited.

\section{References}

Alessi MC, Bastelica D, Morange P, Berthet B, Leduc I, Verdier M, Geel O, Juhan-Vague I (2000) Plasminogen activator inhibitor 1, transforming growth factor-beta1, and BMI are closely associated in human adipose tissue during morbid obesity. Diabetes 49:1374-1380

Antuna-Puente B, Feve B, Fellahi S, Bastard J-P (2008) Adipokines: the missing link between insulin resistance and obesity. Diabetes Metab 34:2-11

Banfi G, Migliorini S, Pedroni F, Galliera E, Dogliotti G, Malavazos AE, Corsi MM (2008) Strenuous exercise activates growth factors and chemokine over-expression in human serum of toplevel triathlon athletes during a competitive season. Clin Chem Lab Med 46:250-252

Czarkowska-Paczek B, Bartlomiejczyk I, Gabrys T, Przybylski J, Nowak M, Paczek L (2005) Lack of relationship between interleukin-6 and CRP levels in healthy male athletes. Immunol Lett 99:136-140

Czarkowska-Paczek B, Bartlomiejczyk I, Przybylski J (2006) The serum levels of growth factors: PDGF, TGF-beta, and VEGF are increased after strenuous physical exercise. J Physiol Pharmacol 57:189-197

Fain JN, Tichansky DS, Madan AK (2005) Transforming growth factor betal release by human tissue is enhanced in obesity. Metabolism 54:1546-1551

Frydelund-Larsen L, Akerstrom T, Nielsen S, Keller P, Keller C, Pedersen BK (2007) Visfatin mRNA expression in human subcutaneous adipose tissue is regulated by exercise. Am J Physiol Endocrinol Metab 292:E23-E31

Gollisch KS, Brandauer J, Jessen N, Toyoda T, Nayer A, Hirshman MF, Goodyear LJ (2009) Effects of exercise training on subcutaneous and visceral adipose tissue in normal- and highfat diet-fed rats. Am J Physiol Endocrinol Metab 297:E495E504

Halbeisen RE, Galgano A, Scherrer T, Gerber AP (2008) Posttranscriptional gene regulation: from genome-wide studies to principles. Cell Moll Life Sci 65:798-813

Huffman KM, Slentz CA, Bales CW, Houmard JA, Kraus WE (2008) Relationships between adipose tissue and cytokine responses to a randomized controlled exercise training intervention. Metabolism 57:577-583

Iam J, Duda DG, Perentes JY, Quadri RS, Fukumura D, Jain RK (2009) Blockade of VEGFR2 and not VEGFR1 can limit dietinduced fat tissue expansion: role of local versus bone marrowderived endothelial cells. PLoS ONE 4:e4974

Kawamura T, Murakami K, Bujo H, Unoki H, Jiang M, Nakayama T, Saito Y (2008) Matrix metalloproteinase-3 enhances the free fatty acid-induced VEGF expression in adipocytes through tolllike receptor 2. Exp Biol Med (Maywood) 233:1213-1221 
Leick L, Lindegaard B, Stensvold D, Plomgaard D, Saltin B, Pilegaard H (2007) Adipose tissue interleukine-18 mRNA and plasma interleukine-18: effect of obesity and exercise. Obesity (Silver Spring) 15:356-363

Livak KJ, Schmittgen TD (2001) Analysis of relative gene expression data using real-time quantitative PCR and the $2^{(-\Delta \Delta C T)}$ method. Methods 25:402-408

Lundby C, Gassman M, Pilegaarg H (2006) Regular endurance training reduces the exercise induced HIF-1alpha and HIF2alpha mRNA expression in human skeletal muscle in normoxic conditions. Eur J Appl Physiol 96:363-369

Mattson MP (2010) Does brown fat protect against diseases of aging? Ageing Res Rev 9:69-76

Molgat AS, Gagnon A, Sorisky A (2009) Preadipocyte apoptosis is prevented by macrophage-conditioned medium in a PDGFdependent manner. Am J Physiol Cell Physiol 296:C757-C765

Pallua N, Pulsfort AK, Suschek C, Wolter TP (2009) Content of the growth factors bFGF, IGF-1, VEGF, and PDGF-BB in freshly harvested lipoaspirate after centrifugation and incubation. Plast Reconstr Surg 123:826-833

Pedersen BK, Febbraio MA (2008) Muscle as an endocrine organ: focus on muscle-derived interleukin-6. Physiol Rev 88: 1379-1406

Pradet-Balade B, Boulme F, Beug H, Müllner EW, Garcia-Sanz HA (2001) Translation control: bridging the gap between genomics and proteomics. Trends Biochem Sci 26:225-229

Rega G, Kaun C, Demyanets S, Pfaffenberger S, Rychli K, Hohensinner PJ, Kastl SP, Speidl WS, Weiss TW, Breuss JM, Furnkranz A, Uhrin P, Zaujec J, Zilberfarb V, Frey M, Roehle R, Maurer G, Huber K, Wojta J (2007) Vascular endothelial growth factor is induced by the inflammatory cytokines interleukin- 6 and onkostatin $m$ in human adipose tissue in vitro and in murine adipose tissue in vivo. Arterioscler Thromb Vasc Biol 7:1587-1595

Richardson RL, Hausman GJ, Wright JT (1998) Growth factor regulation of insulin growth factor (IGF) binding protein
(IGFBP) and preadipocyte differentiation in porcine stromalvascular cell culture. Growth Dev Aging 62:3-12

Sonenberg N, Hinnebusch AG (2009) Regulation of translation initiation in eukaryotes: mechanisms and biological targets. Cell 136:731-745

Tan JT, McLennan SV, Song WW, Lo LW, Bonner JG, Williams PF, Twigg SM (2008) Connective tissue growth factor inhibits adipocyte differentiation. Am J Physiol Cell Physiol 295:40-51

Thompson PD, Buchner D, Pina IL, Thompson PD, Buchner D, Pina IL, Balady GJ, Williams MA, Marcus BH, Berra K, Blair SN, Costa F, Franklin B, Fletcher GF, Gordon NF, Pate RR, Rodriguez BL, Yancey AK, Wenger NK, American Heart Association Council on Clinical Cardiology Subcommittee on Exercise, Rehabilitation, and Prevention; American Heart Association Council on Nutrition, Physical Activity, and Metabolism Subcommittee on Physical Activity (2003) Exercise and physical activity in the prevention and treatment of atherosclerotic cardiovascular disease: a statement from the Council on Clinical Cardiology (Subcommittee on Exercise, Rehabilitation, and Prevention) and the Council on Nutrition, Physical Activity, and Metabolism (Subcommittee on Physical Activity). Circulation 107:3109-3116

Trayhurn P, Wood IS (2004) Adipokines: inflammation and the pleiotropic role of white adipose tissue. Br J Nutr 92:347-355

Trayhurn P, Wang B, Wood IS (2008a) Hypoxia and the endocrine and signalling role of white adipose tissue. Arch Physiol Biochem 114:267-276

Trayhurn P, Wang B, Wood IS (2008b) Hypoxia in adipose tissue: a basis for the dysregulation of tissue function in obesity? $\mathrm{Br} \mathrm{J}$ Nutr 100:227-235

Warren W, Kelsberg G, Bryant S, Fashner J (2005) Can type 2 diabetes be prevented through diet and exercise? J Fam Pract 54:78-80 